\title{
THE CASE FOR PUNISHING THOSE RESPONSIBLE FOR MINIMUM WAGE LAWS, RENT CONTROL AND PROTECTIONIST TARIFFS
}

\author{
Walter E. Block* \\ Harold E. Wirth** \\ Joseph A. Butt***
}

SUMMARY: Introduction; 2 The case; 3 Punishment; 4 Responsibility; 5 Conclusion; Reference.

\begin{abstract}
Most economists oppose minimum wages, rent control and protectionism. The present paper takes this opposition one step further. Well, a few steps further. It attempts to make the case that those responsible for these enactments are criminals and should be punished by law.
\end{abstract}

KEY WORDS: Punishment; Minimum wages; Rent control; Protectionism; Criminality.

\section{INTRODUCTION}

In this essay I shall attempt to make the case for punishing those responsible for minimum wage laws, rent control and protectionist tariffs. Before beginning, however, we do well to ask why we should undertake so quixotic a task in the first place. After all the average reader of this article will, likely, refuse even to read it, dismissing it at the outset as the ravings of a madman. Some will even support these three economic policies as virtuous. They will maintain that minimum wage laws boost remuneration for unskilled workers, that rent control reduces monthly payments for poor tenants and that restrictions on free trade save our jobs. ${ }^{04}$ Instead of punishing those responsible for these public policies, such people will want to reward them, perhaps with medals. ${ }^{05}$ And, even those who are more sophisticated about these matters, and full well realize the devastating harm they impose upon their supposed beneficiaries, will still opine that penalizing those responsible for

\footnotetext{
"Loyola University New Orleans. E-mail: walterblock@cba.loyno.edu

${ }^{* *}$ Loyola University New Orleans

*** Loyola University New Orleans and S.J. College of Business.

${ }_{04}$ "Save "errr jobs" in the vernacular of this South Park episode: http://southpark.cc.com/clips/104259/they-took -our-jobs

${ }^{05}$ We have in mind here most people who voted for Bernie Sanders in 2016
} 
them is beyond the pale; that it is way beyond the realm of civilized discourse to even discuss such a matter, let alone implement it. ${ }^{06}$ Is there to be no protection at all for engaging in free speech, they will ask. So it indeed behooves us to first justify this attempt, before undertaking it.

Section II is given over to establishing the case for punishment. The burden of section III is to delve into the justification for punishment and of IV to analyze responsibility. We conclude in section $\mathrm{V}$.

\section{THE CASE}

What, then, is the case for punishing these malefactors? Simple. They promote policies that not only devastate those as the bottom of the economic pyramid, they also violate their rights. The minimum wage in effect prohibits the unskilled from employment. It condemns them to a life of under and unemployment. Rent control sentences the poor to homelessness; or at the very least moves them in that direction. Restrictive tariffs relieve the poor and indeed all of us, of the benefits of our hard-earned wealth; this is akin to theft.

If I stuck a gun into the face of the poor in the inner city and told them I would shoot them and any would-be employer if they got a job; we would easily know how to characterize me: as a thief. ${ }^{07}$ Suppose I condemned a significant proportion of the poor to homelessness by threatening them with physical violence if they found a place to shelter. Again, we would easily know how to characterize me: as a thief. And the same goes for me if at the point of a pistol I stole a significant proportion of everyone's wealth. But my actions in this regard would have the same identical effects as these three malevolent laws. The minimum wage causes unem-

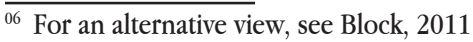

${ }^{07}$ Albeit, admittedly, a rather weird one.
} 
ployment for unskilled workers. ${ }^{08}$ Rent control reduces that quantity and quality of available rental housing. ${ }^{99}$ And tariffs reduce economic welfare. ${ }^{10}$

Why do I choose these three despicable market interferences when there are so many, many more? For example, monetary policy creates the business cycle,$^{11}$ the Food and Drug Administration condemns many innocents to unnecessary deaths ${ }^{12}$ and government road ownership ${ }^{13}$ does the same. The reason is that there is much greater consensus ${ }^{14}$ on the part of professional economists on the three laws I emphasize than on any of these others. And why, pray tell, is that of any relevance? That is because no intelligent person can claim innocence on any of these three as they can for many of these others. According to that old aphorism, "Ignorance of the

08 States Sowell: "Minimum wage laws make it illegal to pay less than the government-specified price for libor. By the simplest and most basic economics, a price artificially raised tends to cause more to be supplied and less to be demanded than when prices are left to be determined by supply and demand in a free market. The result is a surplus, whether the price that is set artificially high is that of farm produce or labor. Making it illegal to pay less than a given amount does not make a worker's productivity worth that amount-and, if it is not, that worker is unlikely to be employed. Yet minimum wage laws are almost always discussed politically in terms of the benefits they confer on workers receiving those wages. Unfortunately, the real minimum wage is always zero, regardless of the laws, and that is the wage that many workers receive in the wake of the creation or escalation of a government-mandated minimum wage, because they either lose their jobs or fail to find jobs when they enter the labor force." For more on this see Baum, 2015; Becker, 1995; Block, 1987, 2000, 2001B, 2002 2014, 2015; Block and Barnett, 2002; Boudreaux, 2015A, 2015B, 2015C, 2016A, 2016B, 2016C, 2016D, 2016E, 2016F, undated; Burkhauser, Couch, Wittenburg, 1996; Caplan, 2013A, 2013B, 2015; Cappelli and Block, 2012; Clemens, 2015; Cooper, 2016; Cordato, 2016; Deere, Murphy and Welch, 1995; Dorobat, 2017; European, undated; Friedman, undated; Gallaway and Adie, 1995; Galles, 2014; Gitis, 2014; Hanke, 2014A, 2014B; Hazlitt, 1946; Howland, 2013; Hunter, 2017; Klein and Dompe, 2007; Landsburg, 2004; Lingenfelter, Dominguez, Garcia, Mayon and Block. 2017; McCaffrey, 2014; McCloskey, 2016; McCormick and Block, 2000; McMaken, 2016A; Mercer, 2015; Murphy, 2014, 2015A, 2015B; Neumark and Wascher, 1992, 1995; Newman, 2016; North, 2014, 2016; Perry, 2016A, 2016B; Powell, 2013; Reisman, 2014, 2016; Rothbard, 1988, 2015A, 2015B; Rustici, 1985; Salerno, 2006; Salihu, 2013; Saltsman, 2015; Schiff, undated; Sohr and Block, 1997; Sowell, 1995, 2000, 2013; Thornton, 2016; Tucker, 2915; Vedder and Gallaway. 2001; Vuk, 2006; Wanniski, 1998; Wenzel, 2013, 2015, 2016; Wiegold, 2014; Williams, 1982, 2013, 2014A, 2014B, 2014C, 2015A, 2015B, 2016, undated.

${ }^{09}$ In 1989, Vietnamee Foreign Minister Nguyen Co Thach averred: "The Americans couldn't destroy Hanoi, but we have destroyed our city by the very low rents." (Dhillon, 2007). According to Lindbeck, 1972: "In many cases, rent control appears to be the most efficient technique presently known to destroy a city except for bombing." In the view of Myrdal, 1965: "Rent control has in certain western countries constituted, maybe, the worst example of poor planning by governments lacking courage and vision." For further elaboration, see Baird, 1980; Block and Olsen, 1981; Block, Horton and Shorter, 1998; Block, 2002C; Dhillon, 2007; Friedman and Stigler, 1946; Grampp, 1950; Grant, 1989; Hayek, 1981; Johnson, 1982; Lindbeck, 1972; Myrdal, 1965; Salins, 1980; Tucker, 1990

${ }^{10}$ Bastiat, 1848; Block, 1976, ch. 23, 2013, ch. 2; Block, Horton and Walker, 1998; Boudreaux, 2010, 2016F, 2016G, 2017; Brandly, 2002; Brown, 1987; Epstein, 2016; Folsum, 1996; Friedman and Friedman, 1997; Gwartney, et. al, 1976; Hazlitt, 1946, ch. 11; Johnsson, 2004; Krasnozhon, Simpson and Block, 2015; Landsburg, 2008; McGee, 1994A, 1994B; McMaken, 2016B; Mullen, 2015; Murphy, 2004; Ricardo, 1821; Roberts, 2016; Rothbard, 2005; Rouanet, 2016; Smith, 1776; Vance, 2016; Williams, 2017

${ }^{11}$ Barnett and Block, 2012; Garrison, 2001; Hayek, 1931; Mises, 1912, 1949; Rothbard, 1975, 1993; Woods, 2009

${ }_{12}$ Becker, 2002; Goodman, 2011; Gottlieb, 2010; Henninger, 1990; Higgs, 1994; Hoppe, 1993; Kaitlin, et. al., 1987; Kazman, 1990; Klein and Tabarrok, Undated; Newman, 2016; Peltzman, 1973, 1974; 1987A, 1987B, 2005; Sardi, 2007; Steinreich, 2005.

${ }_{13}$ Block, 2009

${ }^{14}$ Alston, Kearl and Vaughan, 1992; Block and Walker, 1988, Caplan, 2007; Frey, Pommerehne, Schneider and Gilbert, 1984; Fuller and Geide-Stevenson, 2003; Gordon and Dahl, 2013; Wolfers, 2012 
law is no excuse." That is not true, since there are so many, many laws on the books nowadays. But, in contrast, there are very few economic public policies on which there is greater consensus in the economics profession than this trio. Malefactors thus have less of an excuse regarding the minimum wage law, rent control and tariffs than they do on virtually any other unjustified public policy.

\section{PUNISHMENT}

What about punishment? Must this consist of the death penalty ${ }^{15}$ or even a jail sentence? Maybe. But not necessarily so. There are also lesser forms of approbation. For example, doctors are struck off for medical malpractice, priests and ministers are unfrocked, and lawyers are disbarred for professional misconduct and professors are stripped of their tenure and fired, if their offense is serious enough. Possibly, something along these lines could apply in this case.

It is very rare that a Ph.D. degree is revoked. ${ }^{16}$ Typically, this is done for actions taken before the degree was awarded, such as plagiarism, data falsification, or other such forms of cheating or fraud. But what about actions taken afterward. This is even more rare. ${ }^{17}$ But if a doctor or lawyer is disbarred for conduct unbecoming a professional in one of those callings, it is almost always the case that this is for actions taken after graduation. What about for an economist who publicly misconstrues the effects of minimum wages, rent controls, trade interferences, all of which are part and parcel of Econ 101?

\section{RESPONSIBILITY}

What should constitute "responsibility for?" Who can be deemed sufficiently blameworthy for these three public policies? What degree of culpability should trigger punishment? At the top of the list must be those politicians who enacted these grievous laws, and the policemen, jailors and judges who imposed penalties on law-breakers thereof. They are guilty of initiating violence against innocent people.

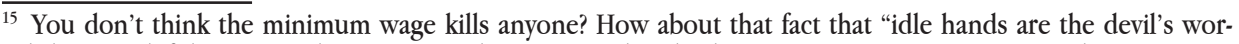
kshop" and if there is anything we can rely upon it is that this law consigns teenagers to unemployment.

${ }_{16}$ Aravosis, 2017; Fleming, 2016; Lewenstein, 2017; Lowe, 2016; Wecker, 2012

${ }^{17}$ Academia Stack Exchange, 2015
} 
Their only crime was the violation of a per se unjust law. They should be considered heroes, not villains (Block, 1976), and those who imposed these penalties should be punished to the full extent of the law.

But would this not unleash the forces of ex post facto law, and would that, itself, not be a violation of rights? No. Reparations are an instance of imposing penalties on those who were only obeying extant law ${ }^{18}$ There is no reason, at least not in principle, for not borrowing a leaf from these other events, and applying them to the actions now in question.

What about low information voters who supported these policies when confronted with the ballot box? Surely, they should share some of the blame, since they were not on the side of the angels; far from it. Rather, the very opposite. But their connection to these policies was a bit more indirect. The lowest rung in legal hell should be reserved for Ph.D. economists who were in a effect traitors to their profession. They knew better, or should have done so. At the very least, they should have their advanced graduate degrees revoked. As for ignorant voters, in comparison, they are almost blameless. They were misled by the so-called leaders in this field. Further, there is a practical difficulty in this regard: the secret ballot and the so-called social contract. ${ }^{19}$ We will never know, we can never know, how to distinguish the innocent from the guilty. However, this will not stop us from considering this matter arguendo. So posit, for the sake of argument that this barrier did not exist. Assume a "God's eye" viewpoint, wherein such knowledge would be fully available to libertarian judges.

We now break this down into two sub categories, direct and indirect. Let us consider the latter first. I voted for Bernie Sanders. ${ }^{20}$ I did so in spite of the fact that the Bern favored a minimum wage. But he also took an anti war position internationally, which I as a libertarian favored. I held my nose and voted for the Senator from Vermont in 2016, because I thought his good international positions outweighed his bad domestic ones. It is difficult to see how I could be held guilty. ${ }^{21}$

Matters are rather different insofar as a plebiscite is concerned. Here, there

\footnotetext{
${ }^{18}$ For example, Nazis. The Nuremberg Trials were an exercise in the violation of ex post facto law. What the Nazis did was fully legal under the law prevailing at the time, and in that place. Similarly, reparations for slavery. This "curious institution" we legal at the time, and, then, later, it was not. For support of reparations for slavery see Alston and Block, 2007; America, 1993; Arceneaux, 2005; Bittker, 1972; Block, 1993, 2001A, 2002B; Block and Yeatts, 1999-2000; Robinson, 1998, 2000, 2002; Ward, 2014; Westley, 1998. For a critique, see Horowitz, 2000, 2002.

${ }^{19}$ DeJasay, 1989; Evers, 1977; Machan, 1983; Outlaw, 2008; Spooner, 1870

${ }^{20}$ I did no such thing, although I did support him vis a vis Hillary Clinton.

${ }^{21}$ It would be nice, but supererogatory if we all adopted the stance of Dr. No, Ron Paul, who voted against any entire package if by one of its elements constituted a rights violation (Block, qw). But it would be a bit much to expect all voters to adopt so exalted a position.
} 
can be no such "balancing" of mitigating factors involved. The issue is now much more clear: violate the rights of innocent people, mainly the poor, or refrain from so doing. Would lack of information constitute a mitigation? If you don't know that minimum wages, rent control and tariffs play economic havoc with the downtrodden, especially, why are you supporting such legislation? According to that aphorism, "Ignorance of the law is no excuse." Well it is, there being so many, many laws, most of them invalid from a libertarian point of view. But, matters are quite different in the present case. "Ignorance of the laws of economics," while voting on a quintessentially economic issue really is no excuse.

\section{CONCLUSION}

A word about the minimum wage law. If it really uplifts wages, why be so niggardly? Why limit ourselves to $\$ 10, \$ 12$ or $\$ 15$ per hour. Why not elevate it to $\$ 1000$ per hour? Then, we would all be rich, at least according to the "logic" employed by the adherents of these enactments. Most "progressives" favor foreign "aid"22 to poor countries. Why not, instead, content themselves with merely advocating that recipient countries cure poverty by installing a very high minimum wage law? Also, we should be aware that the traditional taxi companies attempted to impose a minimum fee for their competitors, Lyft and Uber of $\$ 75$ per trip. ${ }^{23}$ Did they truly think this would belp the latter? To ask this is to answer it: to believe this is to concur with the same economic illiteracy underlying the push for minimum wages.

As for rent control, why not institute a price ceiling for automobiles? For example, I now propose a law forbidding anyone to charge more than $\$ 100$ for a new car. Would this help the poor to better attain this type of transportation? No. They, and all the rest of us, would soon be reduced to riding bicycles and skates.

Regarding interferences with trade, so that "furriners" do not take our jobs, why not institute this at the state level? Without those lousy Texans, we Louisianans could have a thriving cattle industry. Let us ban imports from that jurisdiction. And

\footnotetext{
${ }^{22}$ For a critique, see Alesina and Weder, 2002; Bauer, 1981, 1982, 1984, 1991; Bauer and Yamey, 1957; Castle, 1957; Easterly, 2007; Loeber, 1961; McNeill, 1981; Moyo, 2009; Osterfeld, 1992; Riddell, 1987; Rothbard, 1958; Thornton, 2002; Tucker, 1997; Vance, 2000

${ }^{23}$ https://www.google.com/webhp?sourceid=chrome-instant\&rlz=1C1CHBF_enUS733US733\&ion=1\&esp$\mathrm{v}=2 \& \mathrm{ie}=\mathrm{UTF}-8 \# \mathrm{q}=$ traditional + taxi + companies + attempted + to + impose $+\mathrm{a}+$ minimum + fee + for + their + competitors, + Lyft + and + Uber + of $+\$ 75+$ per + trip $\& *$
} 
the same applies to Maine potatoes, Florida oranges, corn from Iowa and wheat from Nebraska. How dare people from those states "dump" their wares at cut rate prices? No, raise those tariffs! But more. Those rotten people in Baton Rouge are stealing jobs from us virtuous New Orleanians. We need protective tariffs, quotas, even, against job-destroying imports from that evil city. And what of those rascals in Metarie? Ditto. The backs of our hands to them! Of course, in this direction lies selfsufficiency and death for $99 \%$ of the human race, but what is that, compared to the "right" of economic illiterates to vote to interfere with international trade?

Are the people who support policies of this sort really fit to go outside without a leash? Are they really to get away with throwing their political power at the rest of us who yearn only to be free without any punitive repercussion at all? The heavens cry out for at least some sort of penalties for all of them.

\section{REFERENCES}

ACADEMIA STACK EXCHANGE. Can a university retract a degree for actions taken after the degree is awarded? 2015. Available in: < http://academia.stackexchange.com/questions/54807/can-a-university-retract-a-degree-for-actions-taken-after-the-degree-is-awarded $>$.

ARAVOSIS, John. UDPATE: Trump WH aide Monica Crowley steps down over plagiarism. 2017. Available in: < http://americablog.com/2017/01/tell-columbia-investigate -revoke-monica-crowleys-ph-d.html $>$.

ALESINA, Alberto and Beatrice Weder. Do Corrupt Governments Receive Less Foreign Aid? American Economic Review, september 2002

ALSTON, Richard M.; KEARL, J. R.; VAUGHAN, Michael B. Is there a global economic consensus: Is there a consensus among economists in the 1990's? AEA Papers and Proceedings, p. 203-209, May, 1992. Available in: < http://www.weber.edu/wsuimages/AcademicAffairs/ProvostItems/global.pdf $>$.

ALSTON, Wilton D.; BLOCK, Walter E. Reparations, Once Again. Human Rights Review, v. 9, n. 3, p. 379-392, September, 2007. Available in: < http://tinyurl.com/2b$75 \mathrm{fl}>$. 
AMERICA, Richard. Paying the Social Debt: What White America Owes Black America. New York, N.Y.: Praeger, 1993.

ARAVOSIS, John. UDPATE: Trump WH aide Monica Crowley steps down over plagiarism. 2017. Available in: < http://americablog.com/2017/01/tell-columbia-investigate -revoke-monica-crowleys-ph-d.html>.

ARCENEAUX, Taniecea. Reparations for Slavery: A Cause for Reparations, A Case Against David Horowitz. The Review of Black Political Economy, v. 32, n. 3-4, Winter-Spring, p. 141-148, 2005.

BAIRD, Charles. Rent Control: The Perennial Folly. Washington D.C.: The Cato Institute, 1980.

BARNETT, William II; BLOCK, Walter E. Essays in Austrian Economics. New York: Ishi Press, 2012. Available in: <http://www.amazon.com/Essays-Austrian-Economics-William-Barnett/dp/4871873242/ref=sr_1_1?s=books\&ie=UTF8\&qi$\mathrm{d}=1348528287 \& \mathrm{sr}=1-1 \&$ keywords $=$ essays + in + Austrian + economics $>$.

BASTIAT, Frederic. The Balance of Trade. 1848. Available in: < https://mises.org/library/balance-trade $>$.

BAUER, Peter T. Equality, the Third World, and Economic Delusion. Cambridge: Harvard University Press 3 M's, mmm, 1981.

BAUER, Peter T. Ecclesiastical Economics is Envy Exalted. This World, n. 1, Winter/ Spring, p. 56-69, 1982.

BAUER, Peter T. Reality and Rhetoric: Studies in the Economics of Development. Cambridge Mass: Harvard University Press, 1984.

BAUER, Peter T. The Development Frontier: Essays in Applied Economics. Harvester Wheatsheaf, 1991.

BAUER, Peter T.; BASIL. S. Yamey. The Economics of Under-developed Countries. Chicago: The University of Chicago Press, 1957. 
BAUM, Caroline. Caroline Baum Slams Paul Krugman (on minimum wage). July 28; 2015. Available in: <http://www.economicpolicyjournal.com/2015/07/caroline-baum-slams-paul-krugman.html?utm_source $=$ feedburner\&utm_medium $=\mathrm{e}$ mail\&utm_campaign $=$ Feed\%3A + economicpolicyjournal\%2FKpwH $+\% 28$ EconomicPolicyJournal.com\%29>.

BECKER, Gary. It's simple: Hike the minimum wage, and you put people out of work. 1995.

BECKER, Gary. Get the FDA out of the way and drug prices will drop. 2002. Available in: < http://www.businessweek.com/magazine/content/02_37/b3799028.htm>.

BUSINESS WEEK. March 6. p. 22. Available in: < http://www.bloomberg.com/bw/ stories/1995-03-05/its-simple-hike-the-minimum-wage-and-you-put-people-out-of-work>.

BITTKER, Boris I. Reparations: The Case for Black Reparations. Boston: Beacon Press, 1972.

BLOCK, Walter E. Defending the Undefendable. Auburn, AL: The Mises Institute, 2008 [1976]. Available in: < http://mises.org/books/defending.pdf $>$.

BLOCK, Walter. Minimum Wage Law no Help to Unskilled. Dateline Canada: Understanding Economics Through Press Reports, 1987, p. 37.

BLOCK, Walter E. Malcolm X. Fraser Forum, January, p. 18-19, 1993. Available in: $<$ http://mises.org/Community/forums/t/5361.aspx $>$.

BLOCK, Walter. Heritage Stumbles on Minimum Wage. The Free Market, v. 18, n. 10, October, 2000. Available in: < http://www.mises.org/freemarket_detail.asp?control $=324>$.

BLOCK, Walter E. The Moral Dimensions of Poverty, Entitlements and Theft. The Journal of Markets and Morality, v. 4, n. 1, p. 83-93, 2001a.

BLOCK, Walter. The Minimum Wage: A Reply to Card and Krueger. Journal of The Tennessee Economics Association, Spring, 2001b. < http://www.mtsu.edu/ ce- 
coned/100minwg.pdf http://www.mtsu.edu/ ceconed/journal00.htm $>$.

BLOCK, Walter. Delusions of rising wages. New Orleans City Business, v. 28, p. 28, January, 2002a.

BLOCK, Walter E. On Reparations to Blacks for Slavery. Human Rights Review, v. 3, n. 4, p. 53-73, july./september, 2002b. Available in: <http://www.walterblock.com/ wp-content/uploads/publications/reparations_slavery.pdf $>$.

BLOCK, Walter. A critique of the legal and philosophical case for rent control. Journal of Business Ethics, v. 40, p. 75-90, 2002c. Available in: < http://www.mises.org/ etexts/rentcontrol.pdf $>$.

BLOCK, Walter E. The Privatization of Roads and Highways: Human and Economic Factors. Auburn, AL: The Mises Institute, 2009.

BLOCK, Walter E. Toward a Libertarian Theory of Guilt and Punishment for the Crime of Statism. Journal of Libertarian Studies, v. 22, p. 665-675, 2011. Available in: $<$ http://mises.org/journals/jls/22_1/22_1_33.pdf $>$.

BLOCK, Walter E. Defending the Undefendable II: Freedom in all realms. Terra Libertas Publishing House, 2013. Available in: < http://store.mises.org/ Defending-the-Undefendable-2-P10932.aspx > ; < <ttp://www.amazon.com/ Defending-Undefendable-II-Freedom-Realms/dp/1908089377/ref $=$ sr_1_1?ie $=$ UTF8\&qid $=1379098357 \& s r=8-1 \&$ keywords $=$ freedom + in + all + realms $>$.

BLOCK, Walter. The Minimum Wage Law. 2014. Available in: < http://www.lewrockwell.com/2014/01/walter-e-block/want-to-stab-the-poor-and-help-labor-unions/; http://www.economicpolicyjournal.com/2014/01/the-hardcore-austrian-school-and. html $>$.

BLOCK, Walter E. Abolish the minimum wage law. 2015. Available in: https://www. lewrockwell.com/?post_type $=$ article $\& p=561442 \&$ preview $=$ true; https://www.lewrockwell.com/2015/09/walter-e-block/abolish-the-minimum-wage/

BLOCK, Walter; BARNETT II, William. The Living Wage: What's Wrong. The Freeman Ideas on Liberty, v. 52, n. 12, p. 23-24, 2002. 
BLOCK, Walter E.; HORTON, Joseph; SHORTER, Ethan. Rent Control: An Economic Abomination. International Journal of Value Based Management, v. 11, n. 3, p. 253-263, 1998.

BLOCK, Walter; HORTON, Joseph; WALKER, Debbie. The Necessity of Free Trade. Journal of Markets and Morality, v. 1, n. 2, pp. 192-200, October, 1998.

BLOCK, Walter E.; OLSEN, Edgar (Ed.). Rent Control: Myths and Realities. Vancouver: The Fraser Institute, 1981.

BLOCK, Walter E.; WALKER, Michael A. Entropy in the Canadian Economics Profession: Sampling Consensus on the Major Issues. Canadian Public Policy, v. 14, n. 2, p. 137-150, June, 1988. Available in: < http://141.164.133.3/faculty/Block/Blockarticles/Entropy.htm $>$.

BLOCK, Walter E.; YEATTS, Guillermo. The Economics and Ethics of Land Reform: A Critique of the Pontifical Council for Justice and Peace's 'Toward a Better Distribution of Land: The Challenge of Agrarian Reform. Journal of Natural Resources and Environmental Law, v. 15, n. 1, p. 37-69, [1999-2000]. Available in: < http://www. walterblock.com/publications/ethics_land_reform.pdf $>$.

BOUDREAUX, Donald J. On Trade and Currency Manipulation. 2010. Available in: $<$ http://fee.org/freeman/on-trade-and-currency-manipulation/ $>$.

BOUDREAUX, Don. Dartmouth Remarks On the Minimum Wage. 2015a. Available in: < http://www.economicpolicyjournal.com/2015/11/dartmouth-remarks-onminimum-wage.html?utm_source $=$ feedburner\&utm_medium $=$ email\&utm_campaign $=$ Feed $\% 3 \mathrm{~A}+$ economicpolicyjournal\%2FKpwH $+\% 28$ EconomicPolicyJournal . com\%29>.

BOUDREAUX, Don. Noah Smith is no Adam Smith. 2015b. Available in: < http:// www.economicpolicyjournal.com/2015/11/noah-smith-is-no-adam-smith.html?utm_ source $=$ feedburner\&utm_medium $=$ email\&utm_campaign $=$ Feed $\% 3 \mathrm{~A}+$ economicpolicyjournal\%2FKpwH+\%28EconomicPolicyJournal.com\%29>.

BOUDREAUX, Don. Data on the battle: The Minimum Wage vs Automation. 2015c. Available in: <http://www.economicpolicyjournal.com/2015/12/data-on-battle-mi- 
nimum-wage-vs.html?utm_source $=$ feedburner\&utm_medium $=$ email\&utm_campaign $=$ Feed $\% 3 \mathrm{~A}+$ economicpolicyjournal\%2FKpwH $+\% 28$ EconomicPolicyJournal . com\%29>.

BOUDREAUX, Don. Setting the record straight: Automation Caused by Minimum Wage Laws and Otherwise. 2015d. Available in: <http://www.economicpolicyjournal.com/2015/12/setting-record-straight-automation.html?utm_source $=$ feedburner\&utm_medium =email\&utm_campaign $=$ Feed\%3A+economicpolicyjournal\%2FKpwH+\%28EconomicPolicyJournal.com\%29>.

BOUDREAUX, Don. On Further Handicapping the Least Productive. 2016a. Available in: <http://www.economicpolicyjournal.com/2016/06/on-further-handicapping-least-productive.html?utm_source $=$ feedburner\&utm_medium $=\mathrm{e}$ mail\&utm_campaign $=$ Feed $\% 3 \mathrm{~A}+$ economicpolicyjournal\%2FKpw $\overline{\mathrm{H}}+\% 28 \mathrm{Econo}-$ micPolicyJournal.com\%29>.

BOUDREAUX, Don. A Pro Minimum-Wage Professor Believes in Miracles. 2016b. Available in: < http://www.economicpolicyjournal.com/2016/06/a-pro-minimum-wage-professor-believes.html?utm_source $=$ feedburner\&utm_medium $=$ email\&utm campaign $=$ Feed $\% 3 \mathrm{~A}+$ economicpolicyjournal\%2FKpwH $+\% 28$ EconomicPolicyJournal.com\%29>.

BOUDREAUX, Don. What the World Looks Like to Someone Who Doesn't Understand Economics. 2016c. Available in: < http://www.economicpolicyjournal. com/2016/06/what-world-looks-like-to-someone-who.html?utm_source $=$ feedburner\&utm_medium $=$ email\&utm_campaign $=$ Feed $\% 3 \mathrm{~A}+$ economicpolicyjournal\%2FKpwH+\%28EconomicPolicyJournal.com\%29>.

BOUDREAUX, Don. The Inconsistency of People Who Support Higher Tariffs and Who Also Support Higher Minimum Wages. 2016d. Available in: < http://www. economicpolicyjournal.com/2016/08/the-inconsistency-of-people-who-support. html?utm_source $=$ feedburner\&utm_medium $=$ email\&utm_campaign $=$ Fee$\mathrm{d} \% 3 \mathrm{~A}+$ economicpolicyjournal\%2FKpwH+\%28EconomicPolicyJournal.com\%29>.

BOUDREAUX, Don. Why the Minimum Wage is Disgraceful. 2016e. Available in: $<$ http://www.economicpolicyjournal.com/2016/08/why-minimum-wage-is-disgraceful.html?utm_source $=$ feedburner\&utm_medium $=$ email\&utm_campaign $=$ Fee- 
d\%3A+economicpolicyjournal\%2FKpwH+\%28EconomicPolicyJournal.com\%29> .

BOUDREAUX, Don. An Open Letter to Barry Ritholtz. 2016f. Available in: < http:// www.economicpolicyjournal.com/2016/12/an-open-letter-to-barry-ritholtz.html?utm_source $=$ feedburner\&utm_medium $=$ email\&utm_campaign $=$ Feed\%3A+economicpolicyjournal\%2FKpwH+\%28EconomicPolicyJournal.com\%29>.

BOUDREAUX, Donald J. Should Gates clean his own toilets? 2016f. Available in: $<$ http://triblive.com/opinion/donaldboudreaux/10888506-74/workers-gates-wages $>$.

BOUDREAUX, Donald J. On Being Too Rigid \& Dogmatic \& Inflexible on Free Trade. 2016g. Available in: <http://www.economicpolicyjournal.com/2016/12/on-beingtoo-rigid-dogmatic-inflexible.html?utm_source $=$ feedburner\&utm_medium $=\mathrm{e}$ mail\&utm_campaign $=$ Feed $\% 3 \mathrm{~A}+$ economicpolicyjournal\%2FKpwH $+\% 28$ EconomicPolicyJournal.com\%29>.

BOUDREAUX, Don. Trump's Ignorance Is Matched Only by His Thuggishness. 2017. Available in: < http://www.economicpolicyjournal.com/2017/01/trumps-ignorance-is-matched-only-by-his.html?utm_source $=$ feedburner\&utm_medium $=\mathrm{e}$ mail\&utm_campaign $=$ Feed $\% 3 \mathrm{~A}+$ economicpolicyjournal\%2FKpwH $+\% 28$ EconomicPolicyJournal.com\%29>.

BOUDREAUX, Don. Undated. Available in: <http://www.economicpolicyjournal.com/2016/06/the-truth-unseen-consequences-of.html?utm_source $=$ feedburner\&utm_medium $=$ email\&utm_campaign $=$ Feed $\% 3 \mathrm{~A}+$ economicpolicyjournal\%2FKpwH+\%28EconomicPolicyJournal.com\%29>.

BRANDLY, Mark. A Primer on Trade. 2002. Available in: < http://www.mises.org/ article.aspx?Id=1084>.

BROWN, Pamela J. Free Thought and Free Trade: The Analogy Between Scientific and Entrepreneurial Discovery Process. The Journal of Libertarian Studies, v. 8, n. 2, Summer, p. 289-292, 1987. Available in: < http://www.mises.org/journals/ jls/8_2/8_2_8.pdf $>$.

BURKHAUSER, Richard V.; COUCH, Kenneth A.; WITTENBURG, David. Who Gets 
What From Minimum Wage Hikes: A Replication and Re-estimation of Card and Krueger. Industrial and Labor Relations Review, v. 49, n. 3, april, p. 547-552, 1996.

CAPLAN, Bryan. The Myth of the Rational Voter: Why Democracies Choose Bad Policies. Princeton, N.J.: Princeton University Press, 2007.

CAPLAN, Bryan. Phase-In: A Demagogic Theory of the Minimum Wage. 2013a. Available in: <http://econlog.econlib.org/archives/2013/12/phase_in_a_psyc.html>.

CAPLAN, Bryan. The Myopic Empiricism of the Minimum Wage. 2013b. Available in: <http://econlog.econlib.org/archives/2013/03/the_vice_of_sel.html>.

CAPLAN, Bryan. Identificationists Beware. 2015. Available in: < http://econlog. econlib.org/archives/2015/06/identificationi.html>.

CAPLAN, Bryan. IGM, Economic Consensus, and Partisan Bias. 2012. Available in: <http://econlog.econlib.org/archives/2012/07/igm_and_economi.html>.

CAPPELLI, Peter; BLOCK, Walter E. Debate over the minimum wage law. Economics, Management, and Financial Markets, v. 7, n. 4, p. 11-33, dec. 2012. Available in: $<$ http://addletonacademicpublishers.com/abstracts/economics-management-and-financial-markets/volume-7-4-2012/debate-over-the-minimum-wage-law.html>.

CASTLE, Eugene W. The great giveaway: the realities of foreign aid. Chicago, $\mathrm{H}$. Regnery Co, 1957.

CLEMENS, Jeffrey. The minimum wage and the great recession: evidence from the current population survey. 2015. Working Paper 21830. Available in: < http:// papers.nber.org/tmp/57592-w21830.pdf $>$.

COOPER, Preston. Hiking the Minimum Wage Killed Almost as Many Low-End Jobs as Did the Economic Collapse. 2016. Available in: < http://www.economicpolicyjournal.com/2016/01/hiking-minimum-wage-killed-almost-as.html?utm_source =. feedburner\&utm_medium $=$ email\&utm_campaign $=$ Feed $\% 3 \mathrm{~A}+$ economicpolicyjournal\%2FKpwH+\%28EconomicPolicyJournal.com\%29>.

CORDATO, Roy. The Minimum Wage: Taking Away the Right to Work. 2016. Available in: <https://mises.org/blog/minimum-wage-taking-away-right-work>. 
DEERE, Donald; MURPHY, Kevin M.; WELCH, Finis. Employment and the 1990-91 Minimum-Wage Hike. American Economic Review, v. 85, n. 2, p. 232-237, 1995. .

DE JASAY, Anthony. Social Contract, Free Ride: A Study of the Public Goods Problem. Oxford University Press, 1989. Available in: < http://www.amazon.com/SocialContract-Free-Ride-Paperbacks/dp/0198239122/ref=sr_1_1?ie=UTF8\&s=books\&qid $=1200191531 \& s r=1-1>$.

DHILLON, Bob. The perversity of rent controls. National Post, June 28, p. FP15, 2007.

DOROBAT, Carmen Elena. Good Economics Is 'Bizarre' for Minimum Wage Supporters. 2017. Available in: < https://mises.org/blog/good-economics-bizarre-minimum-wage-supporters $>$.

EASTERLY, William. White Man's Burden: Why the West's Efforts to Aid the Rest Have Done So Much Ill and So Little Good; Penguin, 2006.

EPSTEIN, Richard A. The Rise of American Protectionism. 2016. Available in: < http:// www.hoover.org/research/rise-american-protectionism > .

EVERS, Williamson M. Social contract: a critique. The Journal of Libertarian Studies, v. 1, n. 3, p. 185-194, Summer, 1977. Available in: < http://mises.org/journals/ jls $/ 1 \_3 / 1 \_3 \_3 . p d f>$.

FLEMING, Mega. Graduate School Revokes Doctorate For Plagiarism. 2016. Available in: < https://onwardstate.com/2016/03/02/graduate-school-revokes-doctoratefor-plagiarism/ $>$.

FOLSUM, Jr.; BURTON, W. The Industrial Revolution and Free Trade. [s.l.; s.n.], 1996.

FREY, Bruno S.; WERNER, W. Pommerehne, Friedrich Schneider and Guy Gilbert. Consensus and Dissension Among Economists: An Empirical Inquiry. American Economic Review, v. 74, n. 5, p. 986-994, 1984.

FRIEDMAN, Milton; STIGLER, George. Roofs or Ceilings?. 1946. Irvington-on-Hud- 
son: Foundation for Economic Education. Available in: < http://www.fee.org/library/ books/Roofs_or_Ceilings.asp >; reprinted as FRIEDMAN, Milton; STIGLER, George. Roofs or Ceilings?". In: BLOCK, Walter E.; OLSEN, Edgar (Ed.). Rent Control: Myths and Realities. Vancouver: The Fraser Institute, 1981.

FRIEDMAN, Milton; FRIEDMAN, Rose. The Case for Free Trade. Hoover Digest, n. 4, 1997. Available in: < http://www.hooverdigest.org/974/friedman.html>.

FRIEDMAN, Milton. Undated. A minimum-wage law is, in reality, a law that makes it illegal for an employer to hire a person with limited skills. Available in: <http:// izquotes.com/quote/306121; http://books.google.com/books?id=ck6bXqt5shkC\&p$\mathrm{g}=$ PA292\&lpg = PA292\&dq = Playboy + Milton + Friedman $:+\%$ E2\%80\%9CA + minimum-wage + law + is,+ in + reality, $+\mathrm{a}+$ law + that + makes $+\mathrm{it}+\mathrm{illegal}+$ for + an + employer + to + hire $+\mathrm{a}+$ person + with + limited + skills.\%E2\%80\%9D\&sour$\mathrm{ce}=$ bl\&ots $=$ oBhaVzo4_o\&sig $=$ tPYbXajMPWQADdFdRvvbUvXsbs\&hl = en $\&$ $\mathrm{sa}=\mathrm{X} \& \mathrm{ei}=\mathrm{QoU} 4 \mathrm{U}-\mathrm{fSIKeisQTIyoGQBQ \& ved}=0 \mathrm{CDwQ6AEwAw \#} \mathrm{v}=$ onepage $\&$ $\mathrm{q}=$ Playboy\%20Milton\%20Friedman\%3A\%20\%E2\%80\%9CA\%20minimum-wage $\% 20$ law\%20is\%2C\%20in\%20reality\%2C\%20a\%20law\%20that\%20makes\%20it\%20 illegal\%20for\%20an\%20employer\%20to\%20hire\%20a \%20person\%20with\%20limited\%20skills.\%E2\%80\%9D\&f $=$ false $>$.

FULLER, Dan; GEIDE-STEVENSON, Doris. Consensus amongst economists revisited. Journal of Economic Education, v. 34, n. 4, p. 369-378, 2003. Available in: $<$ http://www.jstor.org/discover/10.2307/30042564?uid = 2129\&uid=2134\&ui$\mathrm{d}=2 \&$ uid $=70 \&$ uid $=4 \&$ sid $=21102467797921>$.

GALLAWAY, Lowell; ADIE, Douglas. Review of Card and Krueger's Myth and Measurement: The New Economics of the Minimum Wage. Cato Journal, v. 15, n.1, 1995. Available in: < http://www.cato.org/pubs/journal/cj15n1-8.html>.

GALLES, Gary. Cognitive Dissonance on Minimum Wages and Maximum Rents. 2014. Available in: <https://mises.org/library/cognitive-dissonance-minimum-wages -and-maximum-rents $>$.

GARRISON, Roger W. Time and Money: The Macroeconomics of Capital Structure. London: Routledge, 2001. 
GITIS, Ben. How Minimum Wage Increased Unemployment and Reduced Job Creation in 2013. 2014. Available in: < http://americanactionforum.org/research/how-minimum-wage-increased-unemployment-and-reduced-job-creation-in-2013>.

GOODMAN, John C. How Many Melanoma Patients Did the FDA Kill? 2011. Available in: <http:/healthworkscollective.com/johncgoodman/20968/how-many-melanoma -patients-did-fda-kill $>$.

GORDON, Roger; GORDON, B. Dahl. What Do Economists Think about Major Public Policy Issues? Views among Economists: Professional Consensus or Point-Counterpoint? American Economic Review: Papers \& Proceedings, v. 103, n. 3, p. 629635, 2013. Available in: <http://dx.doi.org/10.1257/aer.103.3.629; http://dss.ucsd. edu/ gdahl/papers/views-among-economists.pdf $>$.

GOTTLIEB, Scott. The FDA Is Evading the Law. The Wall Street Journal, 23 december 2010. Available in: < http://www.aei.org/article/102930>.

GRAMPP, W.S. Some Effects of Rent Control. Southern Economic Journal, April, p. $425-426,1950$.

GRANT, R.W. Rent Control and the War Against the Poor. Manhattan Beach, CA: Quandary House, 1989.

GWARTNEY, James; LAWSON, Robert; BLOCK, Walter E. Economic Freedom of the World, 1975-1995. Vancouver, B.C.: The Fraser Institute, 1996.

HANKE, Steve H. Minimum Wage Laws Kill Jobs. 2014a. Available in: < http://www. cato.org/blog/minimum-wage-laws-kill-jobs $>$.

HANKE, Steve H. Let the Data Speak: The Truth Behind Minimum Wage Laws. Globe Asia, 2014b. Available in: < http://www.cato.org/publications/commentary/letdata-speak-truth-behind-minimum-wage-laws $>$

HAYEK, Friedrich A. Prices and Production. London: Routledg, 1931.

HAYEK, Friedrich A. The Repercussions of Rent Restrictions. In: BLOCK, Walter E. (Ed.) Rent Control: Myths and Realities. Vancouver: The Fraser Institute, 1981.

HAZLITT, Henry. Economics in One Lesson. Auburn, AL: Mises Institute, 2008. 
Available in: < http://mises.org/books/economics_in_one_lesson_hazlitt.pdf $>$.

HENNINGER, Daniel. Will the FDA Revert to Type? The Wall Street Journal, 1990. p. A16.

HIGGS, Robert. Banning a Risky Product Cannot Improve Any Consumer's Welfare (Properly Understood), with Applications to FDA Testing Requirements. The Review of Austrian Economics, v. 7, n.. 2, p. 3-20, 1994. Available in: <http://www. mises.org/journals/rae/pdf/rae7_2_1.pdf $>$.

HOPPE, Hans-Hermann. A Four-Step Health-Care Solution. The Mises Institute Monthly, v. 11, n. 4 ,April, 1993. Available in: < http://mises.org/freemarket_detail. aspx?control $=279>$.

HOROWITZ, David. The latest civil rights disaster: Ten reasons why reparations for slavery are a bad idea for black people and racist too. 2000. Available in: < http:// www.salon.com/news/col/horo/2000/05/30/reparations/index.html > .

HOROWITZ, David. Uncivil Wars: The Controversy over Reparations for Slavery. San Francisco, CA: Encounter Books, 2002.

HOWLAND, David. Increased Minimum Wage, Decreased Economic Prosperity. 2013. Available in: <http://mises.ca/posts/blog/increased-minimum-wage-decreased-economic-prosperity/>.

HUNTER, Brittany. What Puerto Rico Can Teach Us About the Minimum Wage. 2017. Available in: <https://mises.org/blog/what-puerto-rico-can-teach-us-about-minimum-wage $>$.

JOHNSON, M. Bruce (Ed). Resolving the Housing Crisis: Government Policy, Decontrol, and the Public Interest. San Francisco: The Pacific Institute, 1982.

JOHNSSON, Richard C.B. On Ricardo and Free Trade. 2004. Available in: < http:// www.mises.org/article.aspx?Id $=1421 \&>$.

KAITIN, K. I., B. W. Richard; LASAGNA, Louis. Trends in Drug Development: The 1985-86 New Drug Approvals. Journal of Clinical Pharmacology, v. 27, p. 542- 
548, , August, 1987.

KAZMAN, Sam. Deadly Overcaution: FDA's Drug Approval Process. Journal of Regulation and Social Costs, v. 1, n. 1, p. 35-54, september 1990.

KLEIN, Daniel B.; STEWART Dompe. Reasons for Supporting the Minimum Wage: Asking Signatories of the 'Raise the Minimum Wage' Statement. Econ Journal Watch, v. 4, n. 1, p. 125-167, January 2007.

KLEIN, Daniel B.; TABARROK, Alexander. Undated: Is the FDA Safe and Effective? Available in: <http://www.fdareview.org/>.

KRASNOZHON, Leo, SIMPSON, David; BLOCK, Walter E. Fair trade: Its Real Impact on the Working Poor. The Review of Social and Economic Issues (RSEI), v. 1, n. 2, p. 5-28, 2015.

LANDSBURG, Steven E. The sin of wages; the real reason to oppose the minimum wage. Slate, 2004. Available in: <http://slate.msn.com/id/2103486>.

LANDSBURG, Steven E. What to Expect When You're Free Trading. The NY Times. 2008. Available in: <http://www.nytimes.com/2008/01/16/opinion/16landsburg. html?_r $=1 \& s c p=1 \& s q=$ Steven + E. + Landsburg\&oref $=$ slogin $>$.

LEWENSTEIN, Bruce. Has any university ever revoked a PhD for any reason? 2017. Available in: < https://www.quora.com/Has-any-university-ever-revoked-aPhD-for-any-reason $>$.

LINDBECK, Assar. The Political Economy of the New Left. New York: Harper and Row, 1972; cited in RYDENFELT, Sven. The Rise, Fall and Revival of Swedish Rent Control. In: BLOCK, Walter E.; OLSEN, Edgar (Ed.). Rent Control: Myths and Realities. Vancouver: The Fraser Institute, 1981, p. 213-230.

LINGENFELTER, Jonathan et al. Closing the Gap: Why Minimum Wage Laws Disproportionately Harm African-Americans." Economics, Management, and Financial Markets, v. 12, n. 1, p. 11-24, 2017.

LOEBER, Thomas S. Foreign aid: our tragic experiment. New York: Norton, 1961. 
LOWE, Derek. Retracting a PhD Degree, and Heading to Court. 2016. Available in: $<$ http://blogs.sciencemag.org/pipeline/archives/2016/02/09/retracting-a-phd-degree -and-heading-to-court $>$.

MACHAN, Tibor R. Social Contract as a Basis of Norms: A Critique. The Journal of Libertarian Studies, v. 7, n. 1, p. 141-145, Spring, 1983. Available in: < http://mises. org/journals/jls/7_1/7_1_8.pdf >.

MCCAFFREY, Matt. IKEA's 'Minimum Wage. 2014. Available in: < http://www. economicpolicyjournal.com/2014/07/ikeas-minimum-wage.html?utm_source $=$ feedburner\&utm_medium =email\&utm_campaign $=$ Feed $\% 3 \mathrm{~A}+$ economicpolicyjournal\%2FKpwH+\%28EconomicPolicyJournal.com\%29>.

MCCLOSKEY, Deirdre Nansen. The Secret History of the Minimum Wage. The eugenicists' favorite economic regulation. 2016. Available in: < http://reason.com/ archives/2016/06/12/the-secret-history-of-the-mini > .

MCCORMICK, Paul; BLOCK, Walter E. The Minimum Wage: Does it Really Help Workers. Southern Connecticut State University Business Journal, v. 15, n. 2, p. 77-80, Fall-Spring, 2000.

MCGEE, Robert W. A Trade Policy for Free Societies: The Case Against Protectionism. [s.l.]: Quorum Books, 1994a.

MCGEE, Robert W. The Fatal Flaw in NAFTA, GATT and All Other Trade Agreements. Northwestern Journal of International Law \& Business, v. 14, n. 3, p. 549-565, $1994 \mathrm{~b}$.

MCMAKEN, Ryan. Four States Vote to Punish Low-Skilled Workers With Minimum Wage Hikes. 2016a. Available in: < https://mises.org/blog/four-states-vote-punish-low-skilled-workers-minimum-wage-hikes $>$.

MCMAKEN, Ryan. To Oppose Free Trade Is To Embrace Violence. 2016b. Available in: $<$ https://mises.org/library/oppose-free-trade-embrace-violence $>$.

MCNEILL, Desmond. The contradictions of foreign aid. London : Croom Helm, 1981. 
MERCER, Ilana. Minimum Wage, Maximum Folly' In The Ivy League. 2015. Available in: <http://www.economicpolicyjournal.com/2015/05/minimum-wage-maximumfolly-in-ivy-league.html?utm_source $=$ feedburner\&utm_medium =email\&utm campaign $=$ Feed $\% 3 \mathrm{~A}+$ economicpolicyjournal $\% 2 \mathrm{FKpwH}+\% 28$ EconomicPolicyJournal.com\%29>.

MISES, Ludwig von. The Theory of Money and Credit [originally published in German in 1912]. New Haven, CT: Yale University Press, 1953.

MISES, Ludwig von. Human Action. Scholars' Edition. Auburn: Mises Institute, 1998. Available in: <http://mises.org/resources/3250>.

MOYO, Dambisa. Dead Aid: Why Aid is Not Working and How there is a Better Way for Africa, New York, N.Y.: Farrar, Straus and Giroux, 2009.

MULLEN, Tom. Trump's Protectionist Fallacies Have Been Refuted By Free Market Economists for Hundreds of Years. 2015. Available in: < http://www.huffingtonpost.com/tom-mullen/trumps-protectionist-fall_b_8056400.html >.

MURPHY, Robert P. Can Trade Bring Poverty? 2004. Available in: < http://www. mises.org/article.aspx? Id =1699>.

MURPHY, Robert P. Economists debate the minimum wage. 2014. Available in: $<$ http://www.econlib.org/library/Columns/y2014/Murphyminimumwage.html>.

MURPHY, Robert P. The Minimum Wage Experiments. 2015a. Available in: <https://mises.ca/posts/blog/the-minimum-wage-experiments/>.

MURPHY, Robert P. Robert Reich Shills for \$15 Minimum Wage. 2015b. Available in: <https://mises.ca/posts/blog/robert-reich-shills-for-15-minimum-wage/>.

MYRDAL, Gunnar. Opening Address to the Council of International Building Research in Copenhagen; cited In: Dagens Nyheter (Swedish Newspaper), 1965, p. 12; cited in Rydenfelt, Sven, The Rise, Fall and Revival of Swedish Rent Control, In: BLOCK, Walter E.; OLSEN, Edgar (Ed.). Rent Control: Myths and Realities, 1981. Vancouver: The Fraser Institute, p. 224; cited In: BLOCK, Walter E.; OLSEN, Edgar (Ed.). Preface. Rent Control: Myths and Realities. Vancouver: The Fraser Institute, 1981. p. xiv. 
NEUMARK, David; WASCHER, William. Employment Effects of Minimum and Subminimum Wages: Panel Data on State Minimum Wage Laws. Industrial and Labor Relations Review, v. 46, p. 55-81, October 1992.

NEUMARK, David; WASCHER, William. Minimum wage effects on employment and school enrollment. Journal of Business Economics and Statistics. Vol. 13, No. 2, pp. 199-207, 1995.

NEWMAN, Jonathan. California Weighs a \$15 Per Hour Minimum Wage. 2016. Available in: < https://mises.org/blog/california-weighs-15-hour-minimum-wage $>$.

NEWMAN, Jonathan. The Lack of EpiPen Competitors is the FDA's Fault. 2016. Available in: < https://mises.org/blog/lack-epipen-competitors-fdas-fault $>$.

NORTH, Gary. How Minimum Wage Laws Promote Racial Discrimination. 2014. Available in: < http://www.lewrockwell.com/2014/07/gary-north/want -young-black-males-to-get-jobs/ $>$.

NORTH, Gary. Labor Unions and the Minimum Wage: We Got Ours Screw You. 2016. Available in: <https://www.lewrockwell.com/2016/05/gary-north/ got-screw/ $>$.

OSTERFELD, David. Prosperity versus planning: how government stifles economic growth, New York : Oxford University Press, 1992.

OUTLAW, Irish. Social contract my ass. 2008. Available in: < http://mises.org/ community/blogs/irishoutlaw/archive/2008/03/15/social-contract-my-ass.aspx $>$.

PELTZMAN, Sam. Regulation of Pharmaceutical Innovation: The 1962 Amendments. Washington, D.C.: American Enterprise Institute for Public Policy Research, $1974 .$.

PELTZMAN, Sam. Regulation and Health: The Case of Mandatory Prescriptions and an Extension. Managerial and Decision Economics, v. 8, n. 1, p. 41-46, 1987a.

PELTZMAN, Sam. The Health Effects of Mandatory Prescriptions. Journal of Law and Economics, v. 30, n. 2, p. 207-238, 1987b. 
PELTZMAN, Sam. Regulation and the Natural Progress of Opulence. Washington: AEI-Brookings Joint Center on Regulatory Studies, 2005. p. 15-16.

PERRY, Mark. What a $\$ 15$ an Hour Minimum Wage Law Can and Cannot Do. 2016a. Available in: <http://www.economicpolicyjournal.com/2016/05/what-15-hourminimum-wage-law-can-and.html?utm_source $=$ feedburner\&utm_medium $=\mathrm{e}$ mail\&utm_campaign $=$ Feed $\% 3 \mathrm{~A}+$ economicpolicyjournal\%2FKpwH $+\% 28$ EconomicPolicyJournal.com\%29>.

PERRY, Mark. Black Unemployment Matters. 2016b. Available in: < http://www. economicpolicyjournal.com/2016/07/black-unemployment-matters.html?utm_sour$c e=$ feedburner\&utm_medium $=$ email\&utm_campaign $=$ Feed $\% 3 \mathrm{~A}+$ economicpolicyjournal\%2FKpwH+\%28EconomicPolicyJournal.com\%29>.

POWELL, Benjamin. Krugman Contra Krugman on the Minimum Wage? 2013. Available in: < http://www.huffingtonpost.com/ben-powell/krugman-minimum-wage_b_4428174.html $>$.

PELTZMAN, Sam. An Evaluation of Consumer Protection Legislation: The 1962 Drug Amendments. The Journal of Political Economy, v. 81, n. 5, p. 1049-1091, Sept-Oct, 1973.

REISMAN, George. How Minimum Wage Laws Increase Poverty. 2014. Available in: < https://mises.org/library/how-minimum-wage-laws-increase-poverty $>$.

REISMAN, George. The State Against Economic Law: the Case of Minimum Wage Legislation. 2016. Available in: <http://researchroom.economicpolicyjournal. com/2016/01/the-state-against-economic-law-case-of.html $>$.

RICARDO, David. The Principles of Political Economy and Taxation. 3rd ed. London: J. M. Dent, 1912.

RIDDELL, Roger. Foreign aid reconsidered. Baltimore : Johns Hopkins University Press, 1987.

ROBERTS, Russ. The Human Side of Trade. 2016. Available in: < https://medium. com/@russroberts/the-human-side-of-trade-7b8e024e7536\#.nkypmt8hc>. 
ROBINSON, Randall. Defending the Spirit: A Black Life in America. Middlesex, England: Penguin, 1998.

ROBINSON, Randall. The Debt: What America Owes to Blacks. New York, N.Y.: Dutton, 2000 .

ROBINSON, Randall. The Reckoning. Middlesex, England: Penguin, 2002.

ROTHBARD, Murray N. A Hard Look At Foreign Aid. In: SCHOECK, H.; WIGGINS, J. (Ed.). Review of Foreign Aid Reexamined. National Review, 1958. p. 313314.

ROTHBARD, Murray N. America's Great Depression. Kansas City: Sheed and Ward, 1975. Available in: < http://www.mises.org/rothbard/agd.pdf > .

ROTHBARD, Murray N. Outlawing Jobs: The Minimum Wage, Once More. The Free Market. Auburn, AL: The Ludwig von Mises Institute, 1988. Available in: < http:// archive.lewrockwell.com/rothbard/rothbard315.html; http://www.lewrockwell.com/ rothbard/rothbard124.html > .

ROTHBARD, Murray N. Man, Economy, and State. Auburn, AL: Ludwig von Mises Institute, 1993. 2 vol.

ROTHBARD, Murray N. Protectionism and the Destruction of Prosperity. Auburn, AL: The Mises Institute, 2005. Available in: < http://mises.org/rothbard/protectionism.asp $>$.

ROTHBARD, Murray N. On the minimum wage. 2015a. Available in: <http:// www.economicpolicyjournal.com/2015/07/murray-rothbard-on-minimum-wage. html?utm_source $=$ feedburner\&utm_medium $=$ email\&utm_campaign $=$ Fee$\mathrm{d} \% 3 \mathrm{~A}+$ economicpolicyjournal\%2FKpwH+\%28EconomicPolicyJournal.com\%29>.

ROTHBARD, Murray N. The Crippling Nature of Minimum-Wage Laws. 2015b. Available in: $<$ https://mises.ca/posts/articles/the-crippling-nature-of-minimum-wage -laws/>.

ROUANET, Louis. The Case for Unilateral Free Trade. 2016. Available in: < https:// mises.org/blog/case-unilateral-free-trade $>$. 
RUSTICI, Thomas. A public choice view of the minimum wage. Cato Journal, v. 5, n. 1, p. 103-131, 1985. Available in: < http://object.cato.org/sites/cato.org/files/serials/ files/cato-journal/1985/5/cj5n1-6.pdf $>$.

SALERNO, Joseph T. The Indirect Effects of Raising the Minimum Wage. 2006. Available in: < https://mises.org/blog/indirect-effects-raising-minimum-wage >.

SALIHU, Bardhyl N. Bending the Laws of Economics. 2013. Available in: < http:// mises.ca/posts/articles/bending-the-laws-of-economics $>$.

SALINS, Peter D. The Ecolog y of Housing Destruction: Economic Effects of Public Intervention in the Housing Market. New York: New York University Press, 1980.

SALTSMAN, Michael. Minimum Wage Hike Forces a Nonprofit Restaurant to Close. 2015. Available in: <http://www.economicpolicyjournal.com/2015/01/ minimum-wage-hike-forces-nonprofit.html?utm_source = feedburner\&utm_medium $=$ email\&utm_campaign $=$ Feed $\% 3 \mathrm{~A}+$ economicpolicyjournal $\% 2 \mathrm{FKp}$ wH+\%28EconomicPolicyJournal.com\%29>.

SARDI, Bill. The FDA has blood on its hands. 2007. Available in: < http://www. lewrockwell.com/sardi/sardi72.html>.

SCHIFF, Peter. Undated. Available in: < https://www.youtube.com/watch?v=LLr5oWfoWRY\&list=TLC1qFv76XMgWqS88S248kyGa-_uB-d-to $>$.

SMITH, Adam. An Inquiry into the Nature and Causes of the Wealth of Nations. Indianapolis, IN: Liberty Fund, 1979.

SOHR, Kevin and Walter E. Block. The Minimum Wage: The Freeman Ideas on Liberty, 1997. p. 681-682.

SOWELL, Thomas. Repealing the Law of Gravity. Forbes, May 22, p. 82, 1995.

SOWELL, Thomas. Basic Economics: A Citizen's Guide to the Economy. New York, N.Y.: Basic Books, 2000. Available in: < http://www.economicpolicyjournal. com/2016/04/what-is-real-minimum-wage.html?utm_source = feedburner\&utm_ medium $=$ email\&utm_campaign $=$ Feed $\% 3 \mathrm{~A}+$ economicpolicyjournal $\% 2 \mathrm{FKp}$ - 
wH+\%28EconomicPolicyJournal.com $\% 29>$.

SOWELL, Thomas. Why racists love the minimum wage laws. 2013. Available in: < http://nypost.com/2013/09/17/why-racists-love-the-minimum-wage-laws/>.

SPIRO, Andreas. What Do Ron Paul, Northwest Biotherapeutics, And Novartis Have In Common? 2012. Available in: < http://seekingalpha.com/article/856731what-do-ron-paul-northwest-biotherapeutics-and-novartis-have-in-common $>$.

SPOONER, Lysander. No Treason: The Constitution of No Authority and A Letter to Thomas F. Bayard. Larkspur, Colorado: Rampart College, 1966. Available in: < http:// jim.com/treason.htm >.

STEINREICH, Dale. Playing God at the FDA. 2005. Available in: < http://mises.org/ daily/1805>.

THORNTON, Mark. Corruption and Foreign Aid. 2002. Available in: < http://www. mises.org/fullstory.aspx?control $=1093>$.

THORNTON, Mark. Mandating Higher Wages Won't Fix Japan's Economy. 2016. Available in: <https://mises.org/blog/mandating-higher-wages-wont-fix-japans-economy $>$.

TUCKER, Jeffrey. The Marshall Plan Myth. The Free Market, v. 15, n. 9, September, 1997. Available in: <http://www.mises.org/freemarket_detail.asp?control=120\&sortorder $=$ articledate $>$.

TUCKER, Jeffrey. The Eugenics Plot Behind the Minimum Wage: There really was a white male scheme to exterminate African Americans. 2015. Available in: < http:// fee.org/freeman/detail/the-eugenics-plot-of-the-minimum-wage $>$.

TUCKER, William. The Excluded Americans: Homelessness and Housing Policies. Washington D.C.: Regnery Gateway, 1990.

VANCE, Laurence M. The Foreign Aid Debacle. The Free Market, v. 18, n. 12, December, 2000. Available in: <http://www.mises.org/freemarket_detail.asp?control $=334 \&$ sortorder $=$ articledate $>$. 
VANCE, Laurence. Free trade is fair trade. 2016. Available in: < http://www.fff.org/ explore-freedom/article/free-trade-fair-trade/ $>$.

VEDDER, Richard K.; GALLAWAY, Lowell. Does the Minimum Wage Reduce Poverty? Employment Policies Institute, June, 2001. Available in: < http://epionline. org/studies/vedder_06-2001.pdf >.

VUK, Vedran. Professor Stiglitz and the Minimum Wage. 2006. Available in: < http://mises. org/daily/2266charlatan>.

WARD, Victor J. The Curious Case Of Reparations. 2014. Available in: < http://www. economicpolicyjournal.com/2014/09/the-curious-case-of-reparations.html?utm source $=$ feedburner\&utm_medium $=$ email\&utm_campaign $=$ Feed $\% 3 \mathrm{~A}+$ economicpolicyjournal\%2FKpwH+\%28EconomicPolicyJournal.com\%29>.

WANNISKI, Jude. The Way the World Works. 1998. Available in: < https://www. amazon.com/Way-World-Works-Gateway-Contemporary/dp/0895263440/ref=as li_ss_tl?ie $=$ UTF8\&qid $=1484502765 \& s r=8-1 \&$ keywords $=$ The + Way + the + World + Works \&linkCode $=$ sl1\&tag $=$ economiccom0e-20\&linkId $=0$ e06ac29ce51d812feb2f6318f3eee04>.

WECKER, Menachim. 10 High-Profile People Whose Degrees Were Revoked. 2012. Available in: <https://www.usnews.com/education/best-global-universities/ articles/2012/05/02/10-high-profile-people-whose-degrees-were-revoked $>$.

WENZEL, Robert. The Wrong Way to Argue Against Minimum Wage Laws. 2013. Available in: <http://www.economicpolicyjournal.com/2013/02/the-wrong-way-to -argue-against-minimum.html $>$.

WENZEL, Robert. How Minimum Wage Increases Went Bad in San Francisco, Oakland, Seattle and Beyond. 2015. Available in: < http://www.economicpolicyjournal.com/2015/06/how-minimum-wage-increases-went-bad-in.html?utm_sour$\mathrm{ce}=$ feedburner\&utm_medium $=$ email\&utm_campaign $=$ Feed $\% 3 \mathrm{~A}+$ economicpolicyjournal\%2FKpwH+\%28EconomicPolicyJournal.com\%29>.

WENZEL, Robert. Tyler Cowen on the Two Economists That Lefties Use to Prop Up Their Minimum Wage Hike Advocacy. 2016. Available in: < http://www.economicpolicyjournal.com/2016/01/tyler-cowen-on-two-economists-that.html?utm_ 
source $=$ feedburner\&utm_medium $=$ email\&utm_campaign $=$ Feed $\% 3 \mathrm{~A}+$ economicpolicyjournal\%2FKpwH+\%28EconomicPolicyJournal.com\%29>.

WESTLEY, Robert. Many billions gone: is it time to reconsider the case for black reparations? 40 Boston College Law Review, p. 429-476, 1998.

WIEGOLD, Benjamin M. The High Cost of Minimum Wages. 2014. Available in: < https://mises.org/library/high-cost-minimum-wages-0>.

WILLIAMS, Walter E. The State Against Blacks. New York: McGraw-Hill, 1982.

WILLIAMS, Walter E. Higher Minimum Wages. 2013. Available in: < http://archive. lewrockwell.com/williams-w/w-williams158.html>.

WILLIAMS, Walter E. Politics and Minimum Wage. 2014a. Available in: < http:// www.lewrockwell.com/2014/01/walter-e-williams/attacking-those-who-cant-fight - back $/>$.

WILLIAMS, Walter E. The State Against Blacks and the Minimum Wage. 2014b. Available in: <http://www.economicpolicyjournal.com/2014/05/walter-e-williams-state -against-blacks.html?utm_source $=$ feedburner\&utm_medium $=$ email\&utm_campaign $=$ Feed $\% 3 \mathrm{~A}+$ economicpolicyjournal\%2FKpwH $+\% 28$ EconomicPolicyJournal . com\%29>.

WILLIAMS, Walter E. Embarrassing Economists. 2014c. Available in: < http:// www.lewrockwell.com/2014/10/walter-e-williams/embarrassing-economists/> .

WILLIAMS, Walter E. Self-Enforcing Discrimination. 2015a. Available in: <https://www.lewrockwell.com/2015/03/walter-e-williams/minimum-and-maximum-prices/ $>$.

WILLIAMS, Walter E. Embarrassing Economists. 2015b. Available in: < http://researchroom.economicpolicyjournal.com/2015/05/embarrassing-economists.html >.

WILLIAMS, Walter E. The Arrogant Elite. 2016. Available in: < https://www.lewrockwell.com/2016/06/walter-e-williams/arrogant-elite/>. 
WILLIAMS, Walter E. International Trade Thuggery. 2017. Available in: <https://www.lewrockwell.com/2017/01/walter-e-williams/free-trade-3/>.

WILLIAMS, Walter E. Undated. Available in: < http://www.economicpolicyjournal. com/2015/11/powerful-walter-williams-comments-on.html?utm_source $=$ feedburner\&utm_medium = email\&utm_campaign $=$ Feed\%3A+economicpolicyjournal\%2FKpwH+\%28EconomicPolicyJournal.com\%29>.

WOLFERS, Justin. The Secret Consensus Among Economists. 2012. Available in: $<$ http://www.freakonomics.com/2012/07/25/the-secret-consensus-among-economists/>.

WOODS, Thomas E. Jr. Meltdown: A Free-Market Look at Why the Stock Market Collapsed, the Economy Tanked, and Government Bailouts Will Make Things Worse. Washington D.C.: Regnery Publishing, 2009.

Recebido em: 25/01/2018 Aceito em: 21/03/2018 